\title{
Authoritarianism in the Former Soviet Union
}

\author{
Sam G. McFarland \\ Western Kentucky University
}

\author{
Vladimir S. Ageyev \\ Moscow State University, Moscow, Russia \\ Marina A. Abalakina-Paap \\ New Mexico State University
}

\begin{abstract}
Two studies examined the relevance of the authoritarian personality in the Soviet Union. In a 1991 Moscow quota sample, authoritarianism strongly predicted support for reactionary leaders and military actions and opposition to democratic and non-Russian leaders and to democratic activities. The positive correlation between authoritarianism and support for Marxist-Leninist ideology was significant but lower than in 1989. Consistent with the theory that conventionalism is a central attribute of authoritarianism, Russian authoritarianism predicted support for equalitarianism and opposition to laissez-faire individualism, whereas in a comparison American sample these relationships were reversed. The lower Russian consistencies on scales measuring norms of justice are interpreted as differences in how Soviets and Americans relate abstract thought and values to particular policies and activities.
\end{abstract}

The Authoritarian Personality (Adorno, Frenkl-Brunswik, Levinson, \& Sanford, 1950) was published over 4 decades ago, and through the years work on this venerated construct has been extended to a number of non-Western cultures, including Japan (Iwata, 1977), South Africa (Duckitt, 1988), and India (Hassan, 1987). Yet in theSoviet Union, Marxist-Leninist ideology dictated for many years that socialism had created the "new Soviet man" who was not comparable with Western personalities; therefore, concepts such as authoritarianism were by definition inapplicable to Soviet socialist reality (cf. Roshchin, 1980; Shikhirev, 1980, 1985). For these ideological reasons, research on authoritarianism was impossible in the Soviet Union until its last days.

In the West the issue of communist authoritarianism arose quickly after The Authoritarian Personality described that of the political right. Shils (1954) argued cogently, but without data, that Soviet communists displayed the full set of authoritarian characteristics described for fascists. By the mid-1950s, two empirical efforts tried to show that communists and fascists, extremists of the left and right, share a core personality trait akin to authoritarianism. Eysenck (1954) applied his two-factor model of political attitudes and personality and argued that although fascists and communists occupy opposite poles on the dimension of conservative versus radical political attitudes, both are "tough-minded" on the tough-minded versus tenderminded personality dimension. Eysenck found that the $F$ scale used to measure authoritarianism correlated with tough-mind-

This research was supported in part by a grant from the International Research \& Exchanges Board, with funds provided by the Andrew W. Mellon Foundation, the National Endowment for the Humanities, and the U.S. Department of State, and in part by a Faculty Research Grant from Western Kentucky University. None of these organizations is responsible for the views expressed in this article.

Correspondence concerning this article should be addressed to Sam G. McFarland, Department of Psychology, Western Kentucky University, Bowling Green, Kentucky 42101. edness, and because fascists and communists (French and British) were equally tough-minded (Eysenck, 1954; Eysenck \& Coulter, 1972), he concluded that they share a common personality trait that shapes their political attitudes.

However, Christie (1956a, 1956b) and Rokeach and Hanley (1956; Hanley \& Rokeach, 1956) found major methodological problems with Eysenck's sampling, scale scoring, and factor interpretation. Despite Eysenck's (1956a, 1956b) responses to these critiques, dispute continued over the validity of toughmindedness. Altemeyer (1981, pp. 80-89) has reviewed the debate over Eysenck's model and its application to Western communists.

In a second effort, Rokeach (1956) argued that the Authoritarianism scale wrongly fused right-wing ideology with general closed-mindedness and offered his alternative Dogmatism scale to measure "closed cognitive organization, ... beliefs [in] absolute authority, ... [and] patterns of intolerance (p. 3)" without the confound of right-wing ideology. He found that British conservatives and communists were equally high in dogmatism, but conservatives were much higher on the $F$ scale (Rokeach, 1960). However, in five later studies communists and left-wingers scored lower on dogmatism than right-wingers and no higher than those in the political middle, casting doubt on Rokeach's (1960) hypothesis that right-wingers and communists share this trait (Stone, 1980).

Later, Kerlinger $(1967,1984)$ and Ray $(1982)$ presented models with supportive data indicating that the opposite poles of the traditional conservative-liberal dimension of political attitudes are actually orthogonal. To Kerlinger, liberalism and conservatism are orthogonal because they are tied to different sets of core values or "criterial referents" that may be held by the same individual without logical inconsistency. Ray's (1982) scales measuring the kinds of freedom and contral favored by conservatives and those favored by liberals were only slightly correlated. However, Ray's data are insufficient to argue again that Western adherents of left and right ideologies share a common 
authoritarianism (Ray, 1983). Lichter and Rothman (1982) abandoned the effort to find a common personality trait in leftand right-wingers and tried to map the unique personalities of leftists as an "inverted form of authoritarian personality, ... as a cluster of traits leading to rebellion" (p. 207).

Whatever the merits of the search for a common trait in left and right extremists, these efforts should not lightly equate Western leftists and communists with those in communist countries. Altemeyer (1988) suggested sensibly that Western and Soviet communists may be quite different; those in the West may be low in political conformity and its authoritarian correlates, whereas those in communist countries may be high. Indeed, conventionalism, an intensified adherence to cultural norms that has always been viewed as a central feature of authoritarianism (Adorno et al., 1950; Altemeyer, 1981), suggests that authoritarianism and communist beliefs should be negatively related in America but positively related in the Soviet Union where communism was the conventional norm. Duckitt's (1989) recent interpretation of authoritarianism as strong own-group identification also suggests that authoritarianism in any culture should lead to strengthened adherence to owngroup values and rejection of out-group ones. In either view, studies of Western communists could not determine whether Soviet communists were authoritarian.

Despite this limit to the value of the Western studies, our experience compelled us to believe that the authoritarian personality in the Soviet Union, although procommunist, was psychologically the same as Western authoritarianism. Though encased in very different ideologies, both Soviet and Western authoritarianism have appeared to embrace a common conventionalism (including fears of dissidence, free thought, and personal liberty), authoritarian submission, and authoritarian aggression. Whatever the personalities of Western communists, these qualities seemed apt descriptions of Soviet authoritarians.

Following perestroika, it became possible to study personality in the Soviet Union with little ideological constraint. Comparisons with Western countries, previously forbidden and disparaged, could now be conducted. This changing climate allowed us to begin empirical studies of the authoritarian personality in the Soviet Union in 1989 (Abalakina, Ageyev, \& McFarland, 1990; Ageyev, Abalakina, \& McFarland, 1989; McFarland, Ageyev, \& Abalakina, in press). In these first studies we were able to develop balanced and internally consistent Russian-language Ethnocentrism and Authoritarianism scales, the latter largely as a translation of Altemeyer's (1988) 30-item Right-Wing Authoritarianism (RWA) scale. In preparing the Russian scale, 25 of the items were translated precisely. The remaining 5, wedded to Western cultural and religious authorities, required appropriate Soviet substitutes. Hence, we substituted "People should pay less attention to the Marxism-Leninism ..." for "People should pay less attention to the Bible ..." and "Capitalists and those who are out to destroy socialism..." for "Communists and those who are out to destroy religion...." In repeated uses, the Russian scale generally has had slightly higher alphas (about .90), interitem correlations, and item total correlations than the English original.

In a 1989 quota sample of 340 Russian adults, the sums of the 25 common items and of the 5 Soviet culture items correlated .69. In a comparison sample of 463 Kentucky adults, the sums of the 5 American culture items and of the common 25 items correlated .71. In short, although the cultural authorities and enemies were opposite for the two cultures, support for the authorities and opposition to the enemies were components of authoritarianism in both cultures. Whereas Western authoritarianism intensifies condemnation of communists, Soviet authoritarianism in 1989 intensified commitment to communism and opposition to capitalism. Yet we found that Soviet authoritarianism, like its Western counterpart, also induced opposition to democratic ideals and to civil liberties.

Soviet ethnocentrism and its component prejudices (toward Jews, national groups, women, dissidents, etc.) correlated very strongly with authoritarianism, indicating that the authoritarian personality was an important source of ethnocentrism and prejudice in the Soviet Union as it is in the West. Communist party members were higher in authoritarianism than members of national front movements and progressive political organizations. Removing the culture-bound items did not reduce the strength of Russian authoritarianism's relationship with ethnocentrism or with political affiliations. Demographic correlates of authoritarianism in the Soviet Union were strikingly similar to those found in the West, although age correlated more strongly with authoritarianism in the Soviet Union than in North America. The main surprise of our first studies, based initially on our quota sample and later supported in smaller haphazard samples, was that Soviets scored lower in authoritarianism than North Americans, even within groups equated in age and education (McFarland et al., in press). However, the popular rejection of the August 1991 coup makes this finding seem credible.

The present research had two purposes. The first was to explore further the relationship of the authoritarian personality to recent Soviet political attitudes. Specifically, this study examined whether the correlation between Russian authoritarianism and Marxist-Leninist ideology had diminished since 1989 and tested how strongly Russian authoritarianism influenced respect for political leaders and reactions to important political events. The second purpose, based on the theory of authoritarian conventionalism, was to study how authoritarianism in the Soviet Union and the United States influenced support for these cultures' opposite norms of distributive justice. In the Soviet Union, both aims were addressed by a questionnaire. To fulfill the second purpose, a parallel survey was conducted on samples of Kentucky and New Mexico adults.

\section{Study 1}

By 1991, the Communist party was no longer the only legal party, and few people strongly championed Marxist-Leninist ideology. With these changes, it seemed plausible that the link between that ideology and authoritarianism would have become weaker in the 2 years since our first study. If so, the correlation between the 5 Soviet culture items and the remaining 25 items should be weaker than just 2 years earlier.

Nevertheless, the authoritarianism personality is generally related to reactionary political attitudes and preferences for conservative political leaders in both North America (Altemeyer, 1988) and Western Europe (Meleon, Hagendoorn, Raaijmakers, \& Visser, 1988). In our 1989 Kentucky sample, for ex- 
ample, authoritarianism was correlated -.42 with self-ratings of political attitudes on a 5-point spectrum from very conservative to very liberal. Using a 6-point response scale, the RWA means of those who rated themselves as "very conservative" and "very liberal" were 133 and 92, respectively.

We expected that the Soviet correlations between authoritarianism and political conservatism might be stronger than correlations typically found in the West. The Soviet Union from 1989 until August 1991 seemed especially engaged in a political struggle between authoritarian and democratic ideals and policies. The political options were particularly polarized on authoritarian dimensions-ideological purity was opposed by a new openness, and acquiescence to authoritarian leaders was opposed by a new spirit that political legitimacy must come from popular election and respect for liberty. Given the intensity of these struggles, authoritarianism seemed likely to lead to strong positive evaluations of reactionary leaders such as Prime Minister Valentin Pavlov and Party Secretary Ivan Polozkov (both later indicted for their roles in the August coup) and to negative evaluations of progressive reformers such as Russian President Boris Yeltsin and Moscow Mayor Gavril Popov. Similarly, authoritarianism should lead to positive evaluations of dictatorial events such as the actions of the army in quelling independence movements in Lithuania and Latvia in January 1991 and to negative evaluations of pro-reform events such as the huge pro-democracy demonstrations held in March 1991.

\section{Method}

Procedure. To examine these relationships, a survey questionnaire was administered in Moscow in May and June 1991, immediately before Boris Yeltsin's popular election as President of Russia and about 2 months before the abortive coup. The questionnaire contained in order the Authoritarianism scale, 16 items to evaluate 8 prominent Soviet leaders and 8 recent political events on 7 -point scales ranging from -3 (I absolutely disapprove of this political leader/event) to +3 (I absolutely approve of this political leader/event), the distributive justice measures described in Study 2, and demographic items for sex, age, education, and income.

Subjects. The All-Union Survey Research Center selected 163 Moscow residents using a quota-sampling procedure to represent the population distributions for sex, age, and level of education. Researchers paid by the center administered the printed questionnaires in person; the respondents completed them and handed them back to the researchers. Anonymity was assured. The center reported only three refusals to complete the questionnaire; any old Soviet fears of responding to such surveys had evaporated and been replaced by an eagerness to share opinions.

\section{Results}

The sum of the five Soviet-ideology authoritarianism items was again strongly correlated with the remaining items $(r=.45$, $p<.001$ ); as late as June 1991 authoritarianism in the Soviet Union was largely wedded to Marxism-Leninism and opposition to capitalism. However, as expected, this correlation was significantly weaker than the .69 found in $1989(z=3.78$, $p<.001$ ).

A principal axis analysis with oblimin (oblique) rotation of the 16 ratings of leaders and events yielded four factors. The loadings are presented in Table 1. Factor 1, with high loadings on pro-Yeltsin, pro-Shevardnadze (Eduard), and the prodemocracy demonstration of March 28, 1991, was appropriately called Russian Progressivism. Factor 2, National Rights, had high loadings on approval of the results of the Baltic independence referenda, approval of Lithuanian President Vytautas Landsbergis, opposition to the actions of the Soviet army against nationalist groups in the Baltics, and approval of Georgian youths refusing to serve in the Soviet army. Factor 3 was simply a (Mikhail) Gorbachev factor, and Factor 4 was determined by Russian Conservative Leaders. Table 1 also presents the correlations of authoritarianism with reactions to each person and event and with each factor. As Table 1 shows, authoritarianism most strongly predicted attitudes toward the nationalities issues; the higher the respondents' authoritarianism, the more they opposed non-Russian leaders, referenda, and activities and the more they favored the actions of the Soviet army against these movements. Also, as expected, authoritarianism was negatively correlated with Russian progressivism and positively related to ratings of the conservative leaders. At the time of this study, Gorbachev was seen by most Russians as on the conservative side of the political spectrum and as retarding the progressive movement, so we were not surprised that the Gorbachev items and factor also correlated positively with authoritarianism. None of the relationships was due merely to the five Soviet culture items, for none of the correlations with authoritarianism in Table 1 was reduced by more than .03 when the five culture-bound items were removed from the scale.

When the last two factors were reverse scored so that positive scores on all factors were in the liberal direction, the four factors were all significantly correlated, ranging from .22 to .41 with a median of 29 . The sum of the factor scores on these four factors may be taken as a comprehensive measure of liberalism versus conservatism in Soviet political attitudes; this measure was correlated -.63 with authoritarianism, which remained -.62 when the culture-specific items were removed.

\section{Study 2}

Soviet norms of distributive justice (how goods and services are rightfully distributed) were radically different from the ideals held in the United States. Marxist-Leninist norms disparaged laissez-faire individualism (as when housing is determined by one's ability to pay), but this individualism has been positively valued in America. Soviet tradition also condemned wide variations in personal wealth as the West has not. Instead, Soviet ideals emphasized equality - free education and medical care, little disparity in housing or salaries, and so forth-even though in practice party leaders maintained many special privileges. American norms have also opposed distribution on the basis of relative need ("from each according to his ability, to each according to his need"), which Soviet ideals have fostered. Traditionally, American norms have valued equity (as in meritbased salaries) far more than Soviets, although equity became widely advocated under perestroika. Finally, both cultures have formally eschewed status or position as a basis for receiving goods and services, although such practices have been common in both cultures.

The opposing Soviet and American norms of distributive justice offered a unique test of whether conventionalism is a 
Table 1

Principal Axes With Oblique Rotation of Approval Ratings of Russian Leaders and Events

\begin{tabular}{|c|c|c|c|c|c|}
\hline \multirow[b]{2}{*}{ Leaders and events } & \multicolumn{4}{|c|}{ Factor } & \multirow{2}{*}{$\begin{array}{l}\text { Item } r \\
\text { with RWA }\end{array}$} \\
\hline & 1 & 2 & 3 & 4 & \\
\hline President Gorbachev & .01 & -.14 & .73 & .10 & $.19^{*}$ \\
\hline Russian President Yeltsin & .79 & .29 & .02 & -.23 & $-.42^{* *}$ \\
\hline Prime Minister Pavlov & -.17 & .00 & .13 & .59 & $.20^{*}$ \\
\hline Foreign Minister Shevardnadze & .63 & .34 & .11 & -.18 & $-.31 * *$ \\
\hline Lithuanian President Landsbergis & .30 & .55 & .12 & .03 & $-.38^{* *}$ \\
\hline "Soyuz" Leader Alksnis & -.36 & -.19 & -.14 & .74 & $.25^{*}$ \\
\hline Moscow Mayor Popov & .52 & .35 & .18 & -.28 & $-.30^{* *}$ \\
\hline Communist Party Secretary Polozkov & -.47 & -.19 & .24 & .58 & $.36^{* *}$ \\
\hline Result of Baltic independence votes & .36 & .85 & -.09 & -.13 & $-.47^{* *}$ \\
\hline $\begin{array}{l}\text { Shevardnadze's speech warning of } \\
\text { dictator }\end{array}$ & .53 & .32 & -.08 & -.36 & $-.28^{* * *}$ \\
\hline $\begin{array}{l}\text { Army actions in Baltics in January } \\
1991 \\
\text { March referendum to hold USSR }\end{array}$ & -.44 & -.48 & -.01 & .43 & $.41^{* *}$ \\
\hline together & -.18 & -.46 & .21 & .08 & $.33^{* *}$ \\
\hline Yeltsin's call for Gorbachev to resign & .39 & .38 & -.58 & -.09 & $-.40^{* *}$ \\
\hline $\begin{array}{l}\text { Call for Yeltsin to resign as president } \\
\text { Democratic demonstrations of March }\end{array}$ & -.55 & -.26 & .07 & .28 & $.23^{*}$ \\
\hline $\begin{array}{l}1991 \\
\text { Refusal of Georgian youth to serve }\end{array}$ & .85 & .32 & -.23 & -.43 & $-.38^{* *}$ \\
\hline $\begin{array}{l}\text { in Soviet army } \\
\text { Factor correlations with RWA }\end{array}$ & $\begin{array}{r}.31 \\
-.43\end{array}$ & $\begin{array}{r}.71 \\
-.59\end{array}$ & $\begin{array}{r}-.22 \\
.34\end{array}$ & $\begin{array}{r}-.13 \\
.34\end{array}$ & $-.47^{* *}$ \\
\hline
\end{tabular}

Note. Boldfaced data indicate variables that correlate above .50 with each factor. $\mathrm{RWA}=\mathrm{Right}$-Wing Authoritarianism scale. USSR $=$ Union of Soviet Socialist Republics.

${ }^{*} p<.01{ }^{* *} p<.001$.

central feature of authoritarianism. If the authoritarian personality, measured by the same scale, increases commitment to one set of ideals where these are cultural norms and to the opposite ideals where these opposites are the norm, then these results would offer unique and strong support for the link between authoritarianism and conventionalism. In this study it follows that authoritarianism should correlate positively with equality and relative need norms of distributive justice in the Soviet Union but negatively in the United States; laissez-faire individualism and equity should correlate negatively with authoritarianism in the Soviet Union but positively in the United States. It seemed unlikely that authoritarianism would relate to favoring status as a basis for distribution in either culture.

\section{Method}

Procedure. To examine these hypotheses, a 25 -item $5 \times 5$ matrix of norms of distributive justice and relevant content areas was developed. The norms included equality (e.g., "Is it just that medical care should be free and equal for everyone?"), status ("Is it just to distribute goods and privileges on the bases of rank, status, or social position?"), equity ("Is it just that people be paid according to the quality and social benefit of their work?"), relative need ("Is it just that housing be based on need, such as larger families, etc?"), and laissez-faire individualism ("Is it just that housing be based on one's ability to pay?"). Respondents were asked to rate the justice of each principle stated as an abstract principle and in the four content areas of medical care, salaries, housing, and education. Response scales ranged from -3 (I consider it very unjust) to +3 (I consider it very just). A pilot study using 137 Western Kentucky University students found that the five statements measuring each ideal could be summed as scales with alphas ranging from .57 (relative need) to .76 (laissez-faire individualism). Although these alphas were not high, they were adequate to test our specific hypotheses.

Subjects. The distributive justice items were included in the questionnaire administered in Moscow described in Study 1. A parallel English-language questionnaire (excluding reactions to Soviet leaders and events) was administered to 97 Kentucky and 182 New Mexico adults in September 1991. Students enrolled in senior psychology classes administered the questionnaires for course credit. These samples were haphazard, intended only to test our hypotheses. Each student researcher administered at least three questionnaires in person and was instructed to select adults who varied in age from 21 to old age and in education from less than a high school degree to a college degree, with similar numbers of each sex. The students were required to provide the respondents' names and phone numbers on a separate paper (to preserve anonymity) so that random calls could check whether prescribed procedures were followed. Ten calls found no anomalies. Neither authoritarianism nor the hypotheses were described to the student researchers until the completed questionnaires were returned.

\section{Results}

As in our earlier studies, this Soviet sample was approximately 1 point per item lower in authoritarianism on the 6point response scale $(M=86.68, S D=15.31)$ than the combined American sample $(M=115.05, S D=26.57), t(340)=$ $14.14, p<.001 .^{1}$ As before, this difference remained within subsamples equated in age and education.

\footnotetext{
${ }^{1}$ For extended discussion of the mean American-Soviet differences in authoritarianism, see McFarland et al. (in press). Kentucky adults
} 
Table 2 reports descriptive statistics for the five Social Justice scales for Russians and Americans and the correlations of these scales with authoritarianism. As expected, authoritarianism in Russia was positively related to the ideal of equality and negatively related to laissez-faire individualism. In the United States, these correlations were reversed. ${ }^{2}$ American authoritarianism was related to lower evaluation of the norm of relative need distribution, but Soviet authoritarianism did not enhance this norm. Contrary to expectations, the value placed on equity was not related to authoritarianism in either culture; as expected, neither was the value placed on status.

As Table 2 also shows, Americans applied the distributive justice norms with greater consistency across domains than did Soviets. Only the Soviet alpha for laissez-faire individualism approximated the alpha of the American sample, and for the Soviets only the laissez-faire and equality norms had alphas above .50. Because the items were translated carefully, these are likely sample rather than scale differences.

Using only the two scales that were reasonably reliable and significant as predicted for both groups, it was possible to create a general measure of the Soviet norm of distributive justice as the sum of equality plus reverse scored (i.e., rejection of) laissez-faire individualism; this sum correlated .44 ( $p<$ $.001)$ with authoritarianism. The opposite American norm of distributive justice, laissez-faire individualism plus reversescored equality, correlated $31(p<.001)$ with American authoritarianism.

\section{General Discussion}

The rapid demise of communism has deprived Soviet authoritarianism of its ideology. As found in Study 1, Russian authoritarianism in June 1991 was less tied to this ideology than 2 years earlier. Authoritarian personalities will no doubt remain in the former Soviet Union as elsewhere, but the 5 MarxistLeninist culture items seem fully outdated since the August 1991 coup. If so, the 25 common items should still yield an internally consistent scale, but the correlation between these 25 items and the remaining 5 may now be further diminished or eliminated altogether.

However, communist ideology was not essential for Russian authoritarians to support the "law and order" forces and to oppose democratic events and leaders. The authoritarian personality strongly influenced Russian reactions to their political leaders and events and did so with equal strength even when the specific ideological items were removed. Given the strength of correlation between authoritarianism and reactionary conservatism, we doubt that any other personality dimension so powerfully influenced recent Soviet political attitudes. However, if the recent authoritarian-democratic struggle subsides and democratic processes become normal, authoritarianism may be-

were more authoritarian $(M=127.23, S D=22.06)$ than the New Mexico adults $(M=108.64, S D=26.59), t(277)=6.27, p<.001$, who were in turn more authoritarian than the Soviets, $t(277)=9.70, p<.001$. Our earlier samples also found Kentuckians more authoritarian than Americans from other regions and than Canadians, with these still more authoritarian than Russian samples. come less influential in shaping Russian political attitudes and reactions.

The results of Study 2 clearly show that authoritarianism is tied to conventionalism rather than to the specific conservative ideologies found in the West. Authoritarianism is not totally content free; if it were, the items would not cohere as a scale, and certainly, the same items could not cohere in such different cultures. Nevertheless, the same authoritarianism can be expressed as loyalty to different cultural norms, even opposite ones. In all cases, however, this intensified loyalty is coupled with hostility directed toward the culture's deviants, malcontents, and enemies and with support for the use of force against those who are perceived as threats to the accepted order.

Two other results from Study 2 merit comment. First, Table 2 shows that Americans in this study on average ascribed higher value to equality and lower values to equity and laissez-faire individualism than did the Soviets, directly opposite the cultural norms. $T$ tests on these three differences were all significant $(p<.01)$. The haphazard nature of the American sample warrants cautious interpretation of these differences, but the widespread disgust over communism in the Soviet Union at the time of this study had led to a broad rejection of its distributive justice norms, so these differences were not too surprising.

Second, we offer a post hoc interpretation of the much lower Russian alphas on the Distributive Justice scales. We have previously proposed a Mentality-Experience Split Theory (MEST), suggesting that in the Soviet Union the realm of abstract thought and values was isolated from the world of daily experience and behavior (combined under the term activity in Soviet psychology; see Kozulin, 1986) to a far greater degree than in the West (McFarland et al., in press). Each person's activity may have been internally consistent, but both pre-Soviet Russian history and Soviet reality forced the world of activity apart from that of abstract thought and ideals. According to MEST, Soviets generally did not reflect on or orient their daily lives around abstract ideals as much as Americans. Mikheyev (1987) argued similarly that there has been a great separation of the public life from private thought in Soviet life.

The lower internal consistencies on the Distributive Justice scales may reflect this split. Whereas Soviets may have opinions on a particular policy, Americans are more likely to generalize from particular policies to frame abstract values and to, in turn, see particular policies within the context of these abstract values. If the Soviet Equality scale had an alpha of .8 rather than .52 , authoritarianism and equality would have correlated .57 . With similar consistency, the American Equality scale would have correlated -.46 with authoritarianism. These corrections for attenuation are tempting, because they substantially would strengthen support for the authoritarianism-conventionalism relationship. However, it follows from MEST that such corrections would be misguided in the Soviet case, for the lower Russian consistencies on the scales may reflect real differences in Soviet and American thought patterns. This interpretation is clearly post hoc, but the results are consistent with a previously

\footnotetext{
${ }^{2}$ The Kentucky and New Mexico samples yielded similar correlations with authoritarianism, so the samples were combined.
} 
Table 2

Scale Characteristics of Social Justice Scales and Their Correlations

With Soviet and American Authoritarianism

\begin{tabular}{|c|c|c|c|c|c|c|c|c|}
\hline \multirow[b]{2}{*}{ Distributive justice norm } & \multicolumn{4}{|c|}{ Soviet $(n=163)$} & \multicolumn{4}{|c|}{ American $(n=279)$} \\
\hline & $M$ & $S D$ & $\alpha$ & $r$ & $M$ & $S D$ & $\alpha$ & $r$ \\
\hline Equality & 15.9 & 4.0 & .52 & $.36^{* *}$ & 18.6 & 4.7 & .63 & $-.36^{* *}$ \\
\hline Status & 13.4 & 4.0 & .49 & .10 & 11.4 & 4.7 & .73 & .08 \\
\hline Equity & 21.1 & 3.4 & .41 & .03 & 17.1 & 4.8 & .68 & .05 \\
\hline Relative need & 19.7 & 3.5 & .33 & .06 & 18.1 & 4.1 & .50 & $-.19^{*}$ \\
\hline Laissez-faire individualism & 18.6 & 4.8 & .65 & $-.34 * *$ & 16.2 & 4.4 & .67 & $.22^{*}$ \\
\hline
\end{tabular}

${ }^{*} p<.01 .{ }^{* *} p<.001$.

proposed theory. Unfortunately, more direct tests of MEST are not yet clear, and the Soviet-American differences we ascribe to MEST may slowly erode now that the old Soviet system has vanished.

We can now only speculate about the future of Russian authoritarianism and about the personality processes that lead high authoritarians to greater conventionalism. Because authoritarianism apparently requires a strong commitment to an ideology or in-group, it appears that communism, Russian nationalism, and orthodoxy each may appeal to some Russian authoritarians in the near future. Procommunist demonstrations in March 1992 show that these ideals still have a following. Extreme nationalist groups such as Pamyat, although noncommunist, may also provide a natural fit for those with authoritarian sentiments. The two Pamyat members in our 1989 quota sample had extremely high authoritarianism scores. Because authoritarianism is often linked to conservative religion in the West (Altemeyer, 1988), many Russian authoritarians now may find a home in Russian orthodoxy. These developments will be followed with future studies.

Perhaps no one personality process underlies all authoritarian conventionalism. As Greenstein (1975) has suggested, several kinds of authoritarianism such as ego-defensive authoritarianism and cognitive authoritarianism may be reflected in the same scale. Still, one plausible process is worth investigating; high authoritarians may use in-group-out-group distinctions for self-esteem maintenance, whereas low authoritarians do not. High authoritarians do have a greater proneness for framing in-group-out-group distinctions and in-group favoritism, because of Downing and Monaco's finding (1986) that only high authoritarians exhibited in-group favoritism in "minimal groups" (Tajfel, 1982). Furthermore, Lemeyer and Smith (1985) found that the very process of discriminating in minimal groups enhances self-esteem. We expect, however, that this method of self-esteem maintenance is either strengthened by authoritarianism or found exclusively among high authoritarians. Using the minimal group paradigm, we are now studying whether both high and low authoritarians or only high authoritarians enhance their self-esteem through in-group favoritism. If parallel results are found in Russia and America, not only will authoritarianism in these two cultures lead to a common conventionalism, but it will spring from comparable psychological needs as well. In any event, the similarity of Russian and
Western authoritarianism means that these processes can be studied cross-culturally with an eye toward identifying the universal personality features of authoritarianism as well as its different roots and manifestations in different cultures.

\section{References}

Abalakina, M. A., Ageyev, V. S., \& McFarland, S. G. (1990). Avtoritarnaya lichnost $\mathrm{v}$ SShA i SSSR [Authoritarian personality in the U.S.A. and U.S.S.R.]. Chelovek, (6), 110-118.

Adorno, T. W., Frenkl-Brunswik, E., Levinson, D. J., \& Sanford, R. N. (1950). The authoritarian personality. New York: Harper \& Row.

Ageyev, V. S., Abalakina, M. A., \& McFarland, S. G. (1989). Issledovanie Aftoretarezma [Research studies of authoritarianism]. In D. Felos \& V. A. Yadov (Eds.), Sociologicheskiye Isslodevaniya Massovovo Politicheskovo Soznaniya i ProblemyUtverzhdeniya Novovo Politicheskovo Myshleniya, Vyp. 5. (pp. 65-91). Moskva: Akademeya Nauk SSSR Institut Socialogee.

Altemeyer, B. (1981). Right-wing authoritarianism. Winnipeg Ontario, Canada: University of Manitoba Press.

Altemeyer, B. (1988). Enemies of freedom: Understanding right-wing authoritarianism. San Francisco: Jossey-Bass.

Christie, R. (1956a). Eysenck's treatment of the personality of Communists. Psychological Bulletin, 53, 411-430.

Christie, R. (1956b). Some abuses of psychology. Psychological Bulletin, 53, 439-451.

Downing, L., \& Monaco, N. (1986). In-group/out-group bias as a function of differential contact and authoritarian personality. Journal of Social Psychology, 126, 445-452.

Duckitt, J. (1988). Normative conformity and racial prejudice in South Africa. Genetic, Social, and General Psychology Monographs, 114, 413-437.

Duckitt, J. (1989). Authoritarianism and group identification: A new view of an old construct. Political Psychology, 10, 63-84.

Eysenck, H. J. (1954). The psychology of politics. New York: Routledge, Chapman \& Hall.

Eysenck, H. J. (1956a). The psychology of politics: A reply. Psychological Bulletin, 53, 177-182.

Eysenck, H. J. (1956b). The psychology of politics and the personality similarities between fascists and communists. Psychological Bulletin, 53, 431-438.

Eysenck, H. J., \& Coulter, T. J. (1972). The personality and attitudes of working-class British Communists and Fascists. Journal of Social Psychology, 87, 59-73.

Greenstein, F. I. (1975). Personality and politics. In F. I. Greenstein \& 
N. W. Polsby (Eds.), Handbook of political science: Micropolitical theory (Vol. 2, pp. 1-92). Reading, MA: Addison-Wesley.

Hanley, C., \& Rokeach, M. (1956). Care and carelessness in psychology Psychological Bulletin, 53, 183-186.

Hassan, M. K. (1987). Parental behavior, authoritarianism, and prejudice. Manas, 34, 41-50.

Iwata, $O$. (1977). Some attitudinal determinants of environmental concerns. Journal of Social Psychology, 103, 321-322.

Kerlinger, F. N. (1967). Social attitudes and their criterial referents: A structural theory. Psychological Review, 74, 110-122.

Kerlinger, F. N. (1984). Liberalism and conservatism: The nature and structure of social attitudes. Hillsdale, NJ: Erlbaum.

Kozulin, A. (1986). The concept of activity in Soviet psychology: Vygotsky, his disciples and critics. American Psychologist, 41, 264-274.

Lemeyer, L., \& Smith, P. M. (1985). Intergroup discrimination and self-esteem in the minimal group paradigm. Journal of Personality and Social Psychology, 49, 660-670.

Lichter, S. R., \& Rothman, S. (1982). The radical personality: Social psychological correlates of new left ideology. Political Behavior, 4, 207-235.

McFarland, S. G., Ageyev, V. S., \& Abalakina, M. A. (in press). The authoritarian personality in the U.S.A. and U.S.S.R.: Comparative studies. In W. F. Stone, G. Lederer, \& R. Christie (Eds.), Strengths and weaknesses: The authoritarian personality today. New York: Springer-Verlag.

Meleon, J. D., Hagendoorn, L., Raaijmakers, Q., \& Visser, L. (1988). Authoritarianism and the revival of political racism: Reassessments in the Netherlands of the reliability and validity of the concept of authoritarianism by Adorno et al. Political Psychology, 9, 413-429.

Mikheyev, D. (1987). The Soviet mentality. Political Psychology, 8, 491523.
Ray, J. J. (1982). Authoritarianism/liberalism as the second dimension of social attitudes. Journal of Social Psychology, 117, 33-44.

Ray, J. J. (1983). Half of all authoritarians are left-wing: A reply to Eysenck and Stone. Political Psychology, 4, 139-143.

Rokeach, M. (1956). Political and religious dogmatism: An alternative to the authoritarian personality. Psychological Monographs, 70, 18, (Whole No. 425).

Rokeach, M. (1960). The open and closed mind. New York: Basic Books.

Rokeach, M., \& Hanley, C. (1956). Eysenck's tender-minded dimension: A critique. Psychological Bulletin, 53, 169-176.

Roshchin, S. K. (1980). Zapadnaya socialnaya psikhologiya kak instrument idiologii i plolitiki [Western social psychology as an instrument of ideology and politics]. Moscow, Russia: Nauka.

Shikhirev, P. N. (1980). Sovremennaya socialnaya psikhologiya v SShA [Modern social psychology in the U.S.A.]. Moscow, Russia: Nauka.

Shikhirev, P. N. (1985). Sovremennaya socialnaya psikhologiya $v$ zapodnoi Evrope: Methodologicheskie i teoreticheskie problemy [Modern social psychology in Western Europe: Methodological and theoretical problems]. Moscow, Russia: Nauka.

Shils, E. A. (1954). Authoritarianism: "Right" and "left". In R. Christie \& M. Jahoda(Eds.), Studies in the scope and method of "The Authoritarian Personality" New York: Free Press of Glencoe.

Stone, W. F. (1980). The myth of left-wing authoritarianism. Political Psychology, 2, (3-4), 3-19.

Tajfel, H. (1982). Social identity and intergroup relations. Cambridge, England: Cambridge University Press.

Received November 4, 1991

Revision received May 8, 1992

Accepted May 15, 1992 